\title{
Impact of Perceptions of COVID-19 Related Risks on Partner "Social Undermining" of Healthcare Workers Through the Spillover Theory
}

\author{
Somia Sarwar \\ Rameen Medical Complex, Toba Tek Singh, Pakistan. \\ Aisha Sarwar \\ Capital University of Science and Technology, Islamabad, Pakistan. \\ Bahaudin G. Mujtaba \\ (Corresponding Author) \\ Huizenga College of Business and Entrepreneurship \\ Nova Southeastern University \\ ORCID: https://orcid.org/0000-0003-1615-3100 \\ E-mail: mujtaba@nova.edu \\ Zia Ur Rehman Sarwar \\ National University of Science and Technology, \\ Islamabad, Pakistan
}

Received: Jun. 22, $2021 \quad$ Accepted: Jul. 14, $2021 \quad$ Online published: Aug. 3, 2021

doi:10.5296/ijhrs.v11i3.18903ＵRL: https://doi.org/10.5296/ijhrs.v11i3.18903

\begin{abstract}
The health emergency and pandemic at the global level was announced in the early months of 2020 due to the Covid-19 corona virus, and healthcare workers have had to perform their duties in risky circumstances. Consequently, the healthcare professionals are more vulnerable to being infected with the Covid-19 coronavirus. Hence, through the lens of the spillover
\end{abstract}


theory, this study investigates the effect of perceptions of Covid-19 related risks on partner (spouse) "social undermining" via emotional exhaustion. Data was collected in two periods with one-week time lag from 237 healthcare professionals and their partners.

Results revealed that perceptions of Covid-19 related risks increased partner undermining via employee emotional exhaustion. This study contributes to the literature of the current pandemic by investigating the impact of perceptions of Covid-19 related risks on healthcare workers' close relatives. Hospital administrators and policymakers need to develop timely interventions to mitigate or minimize this negative spillover effect. Therefore, practical implications are suggested accordingly.

Keywords: perceptions of COVID-19 related risks, Emotional exhaustion, partner undermining, healthcare workers, coronavirus pandemic

\section{Introduction}

Currently, the world is facing a major challenge in the outbreak of Covid-19 pandemic since the start of 2020 (Sohrabi, Alsafi, O'Neill, Khan, Kerwan, Al-Jabir, and Agha, 2020). Infectious diseases are considered a major threat to workers' physical and mental health (Huang, Han, Luo, Ren, \& Zhou, 2020), especially for healthcare workers because they have more chances of catching the disease due to more interactions with infected patients (Liang \& Acharya, 2020). Covid-19 has become a major health concern for the whole world due to its fast spread of infection through close contact, touching of infected surfaces, coughing, and airborne qualities among millions around the globe with high mortality rates (Gössling, Scott, \& Hall, 2020). According to The Washington Post article,

The novel coronavirus - once concentrated in specific cities or countries has now crept into virtually every corner of the globe and is wreaking havoc in multiple major regions at once. But the impact is not being felt evenly. Poorer nations throughout Latin America, the Middle East, South Asia and Africa are bearing a growing share of the caseload, even as wealthier countries in Western Europe and East Asia enjoy a relative respite after having beaten back the worst effects through rigorously enforced lockdowns (Witte, Sheridan, Slater, and Sly, 2020, para. 3-4).

During the outbreak of SARS (severe acute respiratory syndrome), which was a very dangerous infection (Zhang and Yang, 2020), about one fifth of all the victims were healthcare workers (Chan-Yeung, 2004). Similarly, Covid-19, due to its contagious nature especially in closed spaces and airborne possibilities, is more dangerous for healthcare workers because they treat the patients of this coronavirus through collaborative face-to-face interactions (Wang, Zhou, \& Liu, 2020). Furthermore, literature shows that the perceived risk of an event is linked with unfamiliarity and uncontrollability of hazards (Wu, Fang, Guan, Fan, Kong, Yao, Lu, 2009); and, increased unfamiliarity and uncontrollability of a disease tends to effect employees' mental health more (Wu et al., 2009). Accordingly, a long traumatic exposure to Covid-19 may increase the risk of being infected with this coronavirus, which further increases the negative impact on workers' mental health. As such, it is the responsibility of all medical professionals and policy makers to make sure their essential 
workers remain in good health (Mujtaba and Cavico, 2014) for them to effectively take care of patients who are impacted by the Covid-19 pandemic.

Pandemics may lead employees to chronic stress and mental health problems (Huang \& Zhao, 2020); hence, Covid-19 is not only a risk to an individual's physical health but also to one's psychological and mental health. Although, researchers have considered its effective control in their studies (Yang, Peng, Wang, Guan, Jiang, Xu, Chang, 2020), the psychological and behavioral outcomes of Covid-19 for the long-term are yet to be considered (Ren, Gao, \& Chen, 2020). Hence, there is a need to investigate the psychological effects of Covid-19 outbreak.

We know that the Covid-19 epidemic has created excessive stress and much anxiety amongst some healthcare workers due to its rapid spread and high mortality rates, especially among the elderly and most experienced medical professionals (Roy et al., 2020). More cases are reported worldwide with each passing day, accounting for about 14 million Covid-19 cases as of July 2020. Consequently, emotional exhaustion is widely observed problem in healthcare workers (Dhaini et al., 2018). Furthermore, in China, the outbreak of Covid-19 created many psychological problems in workers, and mental health service has emerged as a serious challenge ( $\mathrm{Li}$ et al., 2020), thus making it more important to study employee emotional exhaustion. Distress of any kind, especially if it is prolonged day after day, can hinder the success of any professional in the modern workplace (Mujtaba, Cavico and Senathip, 2020); as such, based on a solid understanding of the main stressors, managers and leaders can then properly plan, organize, lead, and control the circumstances to make sure all professionals have a good work experience every day which is balanced and supplemented by a healthy personal life (Mujtaba, 2014). According to Zhang and Yang (2020, p. 1)

China's experience in combating the COVID-19 has shown that building a community prevention and control system is essential to control the spread of coronavirus. As the backbone of the epidemic prevention and control system, the community prevention and control system plays an important role in improving the pattern of disorderly medical treatment, screening suspected patients, preventing the input of pathogens, ensuring residents' medical needs, stabilizing public sentiment, reducing disease fear, and maintaining residents' national security. At the same time, it also exposed the problems of the community prevention and control epidemic system in terms of infrastructure, human resources, and internal systems.

As explained by Zhang and Yang (2020), we as researchers, academicians and practitioners all need to protect the livelihood of our society's human resources, especially the challenges associated with keeping healthcare professionals safe so they can take care of each person who becomes ill and a victim of this coronavirus. Before relevant policies can be inacted, we need research and fact-based preventive recommendations that can be consistently applied by all public and private sector leaders (Shaikh and Ali, 2020). As such, this study contributes in literature toward investigating the perceptions of COVID-19 related risks by modifying the existing scale to measure the perceptions of SARS related risks developed by $\mathrm{Wu}$ and 
colleagues (2009). Let us begin by clarifying the basic terminologies and definitions.

Perception of Covid-19 risk is defined as an individual's insights and views of having the probability or chances of being infected with this coronavirus infection and dealing with its inherent related risks. Literature studies have discussed the increase in fears of Covid-19 in individuals (Salisbury, 2020); however, the literature is scarce about emotional exhaustion in healthcare workers due to the perceived risks of Covid-19.

Emotional exhaustion refers to "the organization's excessive emotional demands on the individual during interpersonal interactions, which the individual is unable to manage, thereby leading to exhaustion of emotional resources" (Chen, Chang, \& Wang, 2019, p. 2). Although, researchers have considered the impacts and possible cures of Covid-19 in their studies (Wang, Wang, Ye, \& Liu, 2020), literature is scarce about the spillover of psychological effect of risk of this coronavirus to workers' home domain, especially towards their partners (spouses). Recent research suggests that the effect of workplace stressors may spillover to one's family members (Sarwar, Bashir, \& Karim Khan, 2019), and partners (spouses) are the most immediate relative or family members of workers (i.e., spouse).

Social undermining is defined as the negative opinions about each other, which may prevent the maintenance of positive interpersonal relationships (Hoobler \& Brass, 2006; Taylor, 2015). Partner social undermining refers to "behaviors directed toward the partner that express negative affect or convey a negative evaluation or criticism" (Alfredo et al., 2020, p. $3)$. While some researchers have considered the impact of stressors from one domain to other domain of employees (Rodríguez-Muñoz, Antino, León-Pérez, \& Ruiz-Zorrilla, 2020; Sarwar, Bashir, \& Karim Khan, 2019; Sarwar, Irshad, Zhong, Sarwar, \& Pasha, 2020), the Covid-19 impact on home domain of workers specifically directed towards partners is still an ignored area. Hence, this study is an attempt to fill the gap in literature by investigating the relationship between perceptions of Covid-19 related risks among healthcare workers and partner undermining at home via emotional exhaustion.

This study will help to increase our understanding about the psychological impact of being exposed to the fast spreading, fatal infectious disease Covid-19 outbreak to better respond to such possible future pandemics. Figure 1 shows a proposed research model where perceptions of Covid-19 related risks can affect partner social undermining through "Emotional Exhaustion."

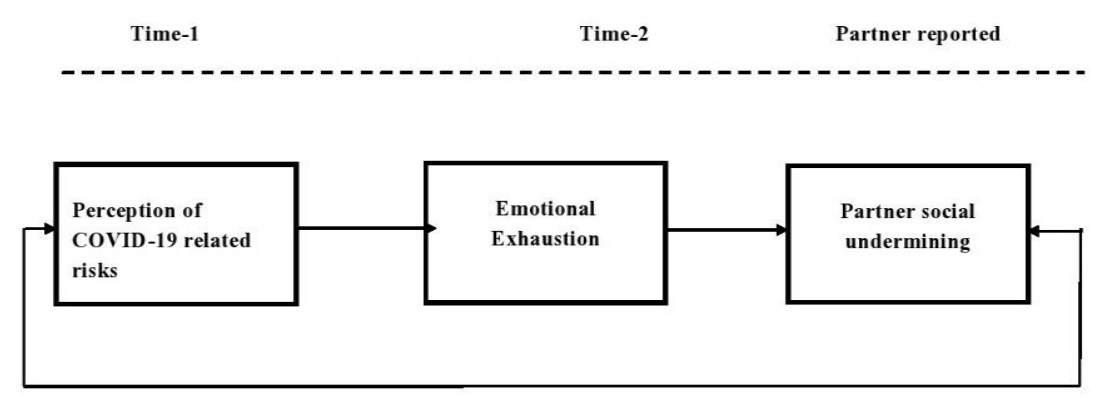

Figure 1. Research Model 


\section{Literature Review}

This study adopted the spillover theory (Staines, 1980) to explain the hypothesized relationships connecting the work and home domains with a focus on the spillover of perceptions and experiences at the workplace to home or from home to work (Judge \& Ilies, 2004; Sonnentag \& Binnewies, 2013). Furthermore, it has been stated that the negative spillover prevails more than the positive ones (Barling \& Macewen, 1992; Sonnentag \& Binnewies, 2013). In addition, according to Sarwar et al. (2019), bullying experienced by employees at the workplace may spillover to one's family in the form of exhibiting family incivility which can easily lead to destructive and even destroyed relationships among spouses. Hence, researchers have discussed about spillover from one domain to another. Accordingly, this study considers the spillover of psychological impacts of risk of Covid-19 on partner undermining via fear about the emotional exhaustion of employees.

\section{Perception of Covid-19 related risk and partner undermining}

Researchers' interest has increased in examining the impact of work stressors on workers' home life since an employee's personal life is likely to have a great impact on his/her professional life and vice versa. As aligned with the spillover theory, literature suggests that experiences at the workplace may "spill over" to family of workers, thereby effecting individuals and personal relationships at home (Alfredo et al., 2020). When there are many tasks that need to be completed at work during any short amount of time, especially when one is being supervised by a task-oriented leader (Mujtaba, Senathip and Sungkhawan, 2021), some of the stressful and negative behaviors at work can be easily displaced or transferred from the workplace to home. Hence, relevant resources should be employed at the workplace to effectively handle all challenges without exhausting the person with undue stress, while leaving some mental resources (energy) for home. Meier and Cho (2019) found that stressors at workplace increases partner social undermining at home. Furthermore, abusive supervision in the organization has been found to have a positive relationship to more arguing with one's partner or spouse at home (Hoobler \& Brass, 2006).

Work family interface model suggests that stressors at the workplace may "spill over" to workers' family, hindering their personal activities and disrupting their well-being (Carlson, Ferguson, Hunter, \& Whitten, 2012; Greenhaus \& Beutell, 1985). Employees experiencing strain-based demands at the workplace have drainage of resources and are often unable to perform family roles appropriately (Sarwar et al., 2019; Trépanier, Fernet, \& Austin, 2013). Accordingly, Liu, Kwan, Lee, and Hui (2013) argued that employees transfer their negative perceptions and emotions from work to family which ultimately may affect their relations with family members.

H1: Perception of Covid-19 related risk has a positive relationship with partner social undermining.

\section{Mediator}

Roles performed by individuals in different domains may interfere with demands of their roles in other domains due to the spillover effects (Greenhaus \& Beutell, 1985). Employees 
experiencing stressors at workplace may feel irritation which can lead them to not show sufficient interest or engagement in family activities (Carlson, Kacmar, \& Williams, 2000). Demanding and challenging workplace stressors may create negative emotions like grief, anxiety, sorrow, and distress spanning employees' work as well as home life (Sarwar et al., 2019; Williams \& Alliger, 1994). This study contributes to literature by considering employees' emotional exhaustion as mediator between perception of Covid-19 related risk and partner undermining. Emotional exhaustion plays the role of mediator between perception of Covid-19 related risk and partner undermining. Emotional exhaustion, which arises from the risk of getting the coronavirus infection, is difficult for workers to leave at the workplace. Therefore, one sphere of life may create hazards for other life spheres. The risk of getting Covid-19 infection may have devastating effects beyond the worker's workplace.

H2: Emotional exhaustion mediates the relationship between perception of Covid-19 related risk and partner undermining.

\section{Methodology}

Hypotheses were tested by collecting data via questionnaires in two-time lags with a gap of one week. Data was collected in different time lags to avoid common method bias (Podsakoff, MacKenzie \& Podsakoff, 2012). Data was collected from $30^{\text {th }}$ of April to $30^{\text {th }}$ of May 2020. On February 26 of 2020, more new virus cases were identified outside of the Chinese territories than inside China. The Covid-19 pandemic was first identified in Pakistan on the $26^{\text {th }}$ of February 2020 based on two cases in Karachi and Islamabad (Ali, 2020). Just 15 days later, cases reached to 20 in Pakistan (14 in Sindh, 5 in Gilgit Baltistan, and 1 in Baluchistan) (Ali, 2020). On a global scale during the time of the data collection, according to Ali (2020), by March 31 the virus had spread to 113 countries and 118,162 cases were registered with 4290 deaths.

The pandemic quickly spread to the entire country of Pakistan when we started the data collection process and when the government announced the official lockdown of all non-essential businesses in the country. So far, more than 202,311 Covid-19 cases have been reported in Pakistan and it is continuing to rise fast (Government of Pakistan, 2020). At global level, as of August 2020 there are over 14 million cases with at least 650,000 deaths from the Covid-19 coronavirus. According to some researchers, Pakistani healthcare workers have been impacted more by this pandemic than any other groups of professionals in the general populations (Junaidi, 2020). Sadly, the rate of new cases shows a sharp rise in Pakistan as well as in other nations around the world during data collection, analysis and writing of this paper.

Due to social distancing rules, data were collected online and through emails. First, data about perceptions of COVID-19 related risks were collected at time one (T1). Secondly, data for emotional exhaustion was collected at time two (T2) after a gap of one week from T1. Data for partner undermining (dependent variable) was also collected at T2. Respondents were assured of confidentiality of their responses. Surveys were accompanied with a cover letter stating the purpose of this study. Unit of analysis for this study was healthcare workers. Healthcare workers were included in sample because they are considered essential as they 
must go to work even during the outbreak of this Covid-19 pandemic. Convenience sampling was employed to collect data for this study.

For this study, a total of 420 questionnaires were distributed at T1, and 310 were received back. Healthcare workers were asked to mention the email identification (ID) of their partners at T1. Thus, 310 respondents were contacted after a gap of one week to collect data about emotional exhaustion and the scale of partner social undermining was sent to partners email IDs at T2. Finally, 237 usable surveys were returned after T2 with a response rate of $56.4 \%$.

\section{Measures}

This study employed previously published scales to collect data. English language is used because it is the official language for communication in Pakistan. Similarly, previous studies used scales in English and reported no language related issues (Sarwar \& Muhammad, 2020; Sarwar, Naseer, \& Zhong, 2020). Therefore, consistent with previous literature, this study used surveys in the English language.

\section{Perceptions of Covid-19 related risk}

Perceptions of Covid-19 risk was measured with 10 items scale developed by Wu et al. (2009) to measure perceptions of SARS related risk. For this current study, 4 items were slightly changed by changing the term "SARS" with "Covid-19", and 6 items were used exactly as before. For example, the original item was "I thought about resigning because of SARS," and it was replaced with "I thought about resigning because of Covid-19".

\section{Emotional exhaustion at work}

Emotional exhaustion at work was assessed via three items scale of the Maslach Burnout Inventory-General Survey (Schaufeli, 1996). It was used recently by Rodríguez-Muñoz et al. (2020) to study bullying, emotional exhaustion, and partner undermining. Respondents were asked to report how often they have experienced such specific events or situations at their workplace during the last week. Sample items include, "This week at work, I felt emotionally drained".

\section{Partner social undermining}

Partner social undermining was measured by 3 items scale of previous researchers (Abbey, Abramis, \& Caplan, 1985). Rodríguez-Muñoz et al. (2020) used this scale to measure partner social undermining. Partners of healthcare workers filled this survey. Sample item includes, "During this week, at home, my partner acted in an unpleasant or angry manner toward me".

\section{Results}

Demographic characteristics are shown in Table 1. In this study, 33.3\% were females and $66.7 \%$ were males. Also, $51.1 \%$ were in the age group of $26-30$, while $47.3 \%$ were in the $36-45$ range, and $1.7 \%$ were 46 years of age and above. In terms of experience, $81 \%$ were having tenure of 1-5 years, while 19\% had a tenure of 5-10 years. Moreover, PLS-SEM was employed to assess the measurement as well as structural model (Hair, Risher, Sarstedt, \& Ringle, 2019). This study employed PLS-SEM for data analysis because it is the most powerful tool to investigate the constructs prediction-orientation. Shmueli et al. (2019) introduced the out-sample prediction technique in PLS-SEM. 
Table 1. Demographics

\begin{tabular}{|c|c|c|c|}
\hline Demographic Characteristics & Frequency & Percent & $\begin{array}{c}\text { Cumulative } \\
\text { Percent }\end{array}$ \\
\hline \multicolumn{4}{|l|}{ Gender } \\
\hline Females & 79 & 33.3 & 33.3 \\
\hline Males & 158 & 66.7 & 100.0 \\
\hline \multicolumn{4}{|l|}{ Age } \\
\hline $26-35$ & 121 & 51.1 & 51.1 \\
\hline $36-45$ & 112 & 47.3 & 98.3 \\
\hline 46 \& above & 4 & 1.7 & 100.0 \\
\hline \multicolumn{4}{|l|}{ Tenure } \\
\hline $1-5$ & 192 & 81 & \\
\hline $5-10$ & 45 & 19 & 100.0 \\
\hline
\end{tabular}

\subsection{Measurement Model}

Constructs reliability and validity is assessed through the measurement model (Hair et al., 2019). Reliability was evaluated through the assessment of composite reliability. Three items (PR2, PR4, PR8) of perceptions of Covid-19 (originally SARS) related risks had low loadings, while the threshold value of loadings is 0.70 (Gefen et al., 2000). Hence, we reassessed the measurement model after deleting these three items. Minimum value for the composite reliability was 0.84 , which was larger than 0.70 (Gefen, Straub, \& Boudreau, 2000). Convergent validity was evaluated through average variance extracted (AVE) (Gefen et al., 2000). Values of AVE were larger than the standard value of 0.50. Table 2 shows the item loadings.

Table 2. Reliability and Validity

\begin{tabular}{|c|c|c|c|c|}
\hline \multicolumn{2}{|c|}{ Measures } & $\mathbf{O L}$ & CR & AVE \\
\hline \multicolumn{2}{|c|}{ Perception of Covid-19 related risks } & & 0.86 & \multirow{8}{*}{0.71} \\
\hline PR1 & $\begin{array}{l}\text { "I believed that my job was putting me at great } \\
\text { risk" }\end{array}$ & 0.68 & & \\
\hline PR3 & "I was afraid of falling ill with Covid-19". & 0.63 & & \\
\hline PR5 & $\begin{array}{l}\text { "I thought I would be unlikely to survive if I } \\
\text { were to get Covid-19". }\end{array}$ & 0.72 & & \\
\hline PR6 & $\begin{array}{l}\text { "I thought about resigning because of } \\
\text { Covid-19". }\end{array}$ & 0.76 & & \\
\hline PR7 & $\begin{array}{l}\text { "I was afraid I would pass Covid-19on to } \\
\text { others". }\end{array}$ & 0.70 & & \\
\hline PR9 & $\begin{array}{l}\text { "People avoided my family because of my } \\
\text { work." }\end{array}$ & 0.69 & & \\
\hline PR10 & $\begin{array}{l}\text { "Because I wanted to help the Covid-19 } \\
\text { patients, I was willing to accept the risks } \\
\text { involved" }\end{array}$ & 0.73 & & \\
\hline \multicolumn{2}{|c|}{ Emotional Exhaustion } & & 0.85 & 0.51 \\
\hline EE1 & “This week, I felt burned out at my work'. & 0.84 & & \\
\hline
\end{tabular}


EE2 "This week, I felt emotionally drained at my 0.87 work

EE3 "This week, I felt downhearted

0.81

Partner social undermining

PSU1 "During this week, at home, my partner acted in 0.84

0.84

0.65 an unpleasant or angry manner toward me".

PSU2 "During this week, at home, my partner 0.83 misunderstood the way i thought and felt about things"

PSU3 "During this week, at home, my partner done things that conflicted with my own sense of what should be done"

OL= Outer Loadings, $\mathbf{C R}=$ Composite Reliability, AVE= Average Variance Extracted

Discriminant validity was assessed through heterotrait-monotrait ratio (HTMT) criteria (Henseler, Ringle, \& Sarstedt, 2015). Values are shown in Table 3. HTMT values are acceptable when they are smaller than 0.90 .

Table 3. Discriminant Validity of Measurement Model (Heterotrait-monotrait Ratio (HTMT) of Correlations)

\begin{tabular}{llcl}
\hline Constructs & EE & PR & PU \\
EE & & & \\
PR & & 0.74 & \\
PU & & 0.81 & 0.84 \\
\hline
\end{tabular}

\subsection{Structural Model}

Structural model assesses the effect sizes f2, predictive relevance Q2, T-values, coefficient of determination (R2) and out sample prediction (Hair et al., 2019). T values were assessed through 5000 bootstrapping procedure (Hair et al., 2019). As presented in Table 4 the impact of perception of Covid-19 related risk on partner undermining (H1) was accepted $(\beta=-0.44$, $\mathrm{p}=0.000)$.

Table 4. Analysis of Structural Model (Hypotheses testing)

\begin{tabular}{ccccccccccc}
\hline Hypothesis & $\begin{array}{c}\text { Relationship } \\
\mathbf{S}\end{array}$ & $\boldsymbol{\beta}$ & $\mathbf{S E}$ & $\begin{array}{c}\text { t-valu } \\
\text { es }\end{array}$ & $\begin{array}{l}\mathbf{P} \\
\text { values }\end{array}$ & $\mathbf{f}^{2}$ & $\mathbf{R}^{2}$ & $\mathbf{Q}^{2}$ & Decision \\
$\mathrm{H} 1$ & $\mathrm{PR} \rightarrow \mathrm{PU}$ & 0.44 & 0.06 & 6.59 & 0.000 & 0.25 & 0.51 & 0.31 & Accepted \\
\hline
\end{tabular}

Furthermore, mediation was checked by investigating confidence intervals and employing Preacher and Hayes' (2008) approach with 5000 bootstrapping. Results are shown in Table 5 which reveals that $\mathrm{H} 2$ was accepted as per the p-value of 0.000 in confidence intervals (Preacher \& Hayes, 2008).

Table 5. Analysis of Mediation

\begin{tabular}{llllcllll}
\hline Hypothesis & Relationships & B & SE & t-values & P & & CI.95 & Decision \\
& & & & & values & & & \\
& & & & & & $2.50 \%$ & $97.50 \%$ & \\
$\mathrm{H} 2$ & $\mathrm{PR} \rightarrow \mathrm{EE} \rightarrow \mathrm{PU}$ & 0.22 & 0.04 & 5.28 & 0.000 & 0.143 & 0.305 & Accepted \\
\hline
\end{tabular}


Finally, $\mathrm{Q}^{2}$ and $\mathrm{R}^{2}$ were also assessed through PLS-SEM. $\mathrm{Q}^{2}$ and $\mathrm{R}^{2}$ show predictive relevance. Moreover, $\mathrm{f}^{2}$ had a value of 0.25 which is acceptable because Cohen (1988) described that $0.02,0.15$ and 0.35 of $\mathrm{f}^{2}$ small, moderate and large. Similarly, out sample prediction technique is suggested for conducting prediction analysis. PLS-Predict was evaluated via PLS-Predict (Shmueli et al., 2019). Results are shown in Table 6.

Table 6. Out Sample Prediction

\section{PLS-MAE LM-MAE}

\begin{tabular}{lll} 
EE1 & 0.73 & 0.74 \\
EE2 & 0.65 & 0.67 \\
EE3 & 0.64 & 0.62 \\
PU1 & 0.61 & 0.64 \\
PU2 & 0.67 & 0.68 \\
PU3 & 0.69 & 0.71 \\
\hline
\end{tabular}

\section{Discussion}

The aim of this study was to investigate and explain how perceptions of Covid-19 related risks may result in workers' behaviors of social undermining toward their partners through emotional exhaustion. The World Health Organization (WHO) officials recommended that all countries must work on early detection of Covid-19 cases, clinical management, and proper quarantine procedures to reduce the spread of the virus (Ali, 2020). Hence, due to the worst effects of Covid-19, most people around the world have been following quarantine rules where nonessential employees stay home or work from home, but healthcare workers perform their tasks, duties and responsibilities in severe and dangerous circumstances in hospitals as they work directly with their patients through close and personal contact. The findings suggest that perceived Covid-19 related risks of healthcare professionals trigger workers to show behaviors of social undermining towards their partners. The findings are consistent with previously published literature as Rodríguez-Muñoz et al. (2020) found that stressors like workplace bullying lead employees to show behaviors of social undermining towards their partners and family members at home. Similarly, Sarwar et al. (2019) found that workplace stressors lead employees to exhibit family incivility towards their family members. The results are consistent with spillover theory, as Staines (1980) argued that employees' emotions at the workplace change as well as influence their emotions along with their behaviors at home.

Healthcare workers regularly experience Covid-19 related risks as they perform their normal duties. Therefore, healthcare workers are facing mental health issues and energy drainage due to Covid-19 related risks. This study covered this gap in literature and considered healthcare workers' Covid-19 related risks. This study proposed and tested emotional exhaustion as mediator between perception of Covid-19 related risks and partner social undermining.

The findings of this study suggests that the perception of Covid-19 related risks lead workers to experience emotional exhaustion which further leads to behaviors of social undermining towards their partners or spouses at home. Consistent with previous studies, literature also 
has documented that emotional exhaustion is increased during pandemics ( $\mathrm{Sun}, \mathrm{Wu}, \mathrm{Qu}, \mathrm{Lu}$, \& Wang, 2014). Excessive emotional exhaustion at work may cause drainage of energy in workers, while partner social undermining may also be due to less social support from their partners. The resource drainage processes may leave few or little energy resources for employees to effectively deal with both work and home demands. The study by Sarwar et al. (2019) found that negative emotion is the mechanism through which the consequence of stressors at the workplace is transferred to family incivility in one's personal life. These findings suggest that chronic stressors at the workplace tend to drain an employee's physical and psychological resources, thereby negatively effecting workers' emotions, while leading them to exhibit inappropriate behaviors in their personal lives with family members. These findings are consistent with the perspective of self-regulation which highlights that having appropriate resources are important to regulate emotions as they effect employees' behaviors later in their personal lives (Baumeister \& Vohs, 2003). Hence, changes in employees' emotions due to stressors at the workplace may lead them to show negative behaviors with their spouses and other family members.

\section{Theoretical implications}

This study offers many theoretical implications. Firstly, this study extends literature on spillover effect domain by examining whether healthcare workers' partner undermining could be expected by perceptions of Covid-19 related risk. By employing a time lag study design, this research revealed that stressors experienced by workers in one domain may be transferred to other domains of life via emotional exhaustion of employees (Sarwar, Irshad, et al., 2020). This finding is in support of the spillover theory (Staines, 1980), which describes the impact of stressors transfer from one context (such as professional work life) to another (i.e. personal life at home). This study is unique in focusing on healthcare workers in Pakistan during the Covid-19 pandemic. We chose healthcare workers because it is a stressful profession, especially now during this Covid-19 pandemic (Sarwar, Irshad, et al., 2020; Sarwar, Naseer, et al., 2020), and we all know that physically and mentally successful healthcare professionals are essential in order for life to get back to normal for all members of society around the globe.

Of course, there are many barriers to the effective management of Covid-19 coronavirus and taking care of healthcare professionals is just one important area to reduce the spread of this infection. There are many other barriers and strategies which should be researched academically and implemented practically to effectively reduce the spread and negative impact of Covid-19 infection. According to recent research,

The rapid spread of the epidemic has impeded the control and prevention efforts. Ground-level management has faced tremendous challenges in a myriad of aspects, including: (a) weak infrastructures: the communities lack solid basis and have suffered from insufficient resources and shortages of necessary personal protective equipment (PPE) and materials; (b) shortage in the work force: there has been a huge gap in the community staffing, which makes it very difficult to meet the heavy workloads of infectious disease 
control; (c) management system flaws: the authorities and responsibilities of the community workers were not defined, and the divisions of tasks were unclear; (d) poor compliance of the residents: some residents were not cooperative and the necessary guidance to manage these people were missing (Zhang and Yang, 2020, p. 3).

\section{Practical implications}

This study extends knowledge in spillover domain and suggests many practical implications for hospitals. Our findings suggest that perceptions about Covid-19 related risks have positive effect on partners' social undermining among healthcare workers. Hence, hospital management should minimize these risks for workers to reduce or mitigate any negative impact or the chances of spillover effect. This can be done by providing all employees, especially healthcare professionals, a safe working environment with sufficient and relevant personal protection equipment (PPEs) and regularly counseling them to minimize such Covid-19 related risks. Our findings also suggest that emotional exhaustion is the mechanism through which employees' perceptions of risk trigger them to exhibit partner social undermining. Hence hospital management needs to enhance positive experiences of their workers. Furthermore, practices of family support should be promoted. Accordingly, Hammer, Kossek, Anger, Bodner, and Zimmerman (2011) recommend that hospitals should invest time and resources to develop supervisors who may provide support to the family of healthcare workers. To make sure that healthcare workers are successfully equipped to effectively handle workplace stressors, management of hospitals should be supportive to provide a safe work environment (Mujtaba, Cavico and Senathip, 2020). As many medical professionals, researchers and authors have clearly stated, we are still dealing with the Covid-19 coronavirus, and it remains an arduous and determined enemy for humanity all over the globe:

Nearly all the countries struggling with a surge share something in common: After weeks or months of trying to suppress the virus, they reopened their economies, only to find that the virus came roaring back. Now they are using a more limited arsenal to contain the spread, with little success..."Let me be blunt: too many countries are headed in the wrong direction," World Health Organization chief Tedros Adhanom Ghebreyesus declared in Geneva this week. "The virus remains public enemy number one, but the actions of many governments and people do not reflect this" (Witte, Sheridan, Slater, and Sly, 2020, para. 7-8).

\section{Limitations and future recommendations}

This study investigated the spillover of perception of Covid-19 risk to partner social undermining. We want to acknowledge some of the inherent limitations. For instance, this study did not investigate the demographics variables with outcomes as considering them may lead to different results. Future researchers should investigate the perceptions of Covid-19 related risk with other outcomes like family communication, family incivility and family functioning. This study of spillover further paves the way for more investigations of 
perceived Covid-19 risk in other social roles of healthcare professionals like coworkers and parents. Moreover, future studies may also consider other potential mediators to increase our understanding of employees' perceptions and outcomes. Future researchers should focus on the all the aspects of his/her partner not on just mental health; for example, authors can review the sexual health of partners during and after Covid-19 pandemic period as this can be a very important element when one talks about his/her partner.

\section{Conflict of Interest}

There is no conflict of interest. This research was self-funded by the authors.

\section{References}

Abbey, A., Abramis, D. J., \& Caplan, R. D. (1985). Effects of different sources of social support and social conflict on emotional well-being. Basic and Applied Social Psychology, 6(2), 111-129.

Ahorsu, D. K., Lin, C. Y., Imani, V., Saffari, M., Griffiths, M. D., \& Pakpour, A. H. (2020). The Fear of Covid-19 Scale: Development and Initial Validation. International Journal of Mental Health and Addiction, 1-9. Advance online publication. https://doi.org/10.1007/s11469-020-00270-8

Ali I. Pakistan confirms first two cases of coronavirus, govt says "no need to panic". https://www.dawn.com/news/amp/15367 92.

Alfredo, R.-M., Mirko, A., José, M., \& Paula, R. Z. Workplace Bullying, Emotional Exhaustion, and Partner Social Undermining: A Weekly Diary Study. Journal of Interpersonal Violence. https://doi.org/10.1177/0886260520933031

Barling, J., \& Macewen, K. E. (1992). Linking work experiences to facets of marital functioning. Journal of Organizational Behavior, 13(6), 573-583.

Baumeister, R. F., \& Vohs, K. D. (2003). Self-regulation and the executive function of the self. Handbook of self and identity, 1, 197-217.

Carlson, D., Ferguson, M., Hunter, E., \& Whitten, D. (2012). Abusive supervision and work-family conflict: The path through emotional labor and burnout. Leadership Quarterly, 23(5), 849-859.

Carlson, D. S., Kacmar, K. M., \& Williams, L. J. (2000). Construction and initial validation of a multidimensional measure of work-family conflict. Journal of Vocational Behavior, 56(2), 249-276.

Chan-Yeung, M. (2004). Severe acute respiratory syndrome (SARS) and healthcare workers. International Journal of Occupational and Environmental Health, 10(4), 421-427.

Cohen, J. (1988). The $\mathrm{t}$ test for means. Statistical power analysis for the behavioural sciences: Hillsdale, NJ: Lawrence Erlbaum Associates.

Dhaini, S. R., Denhaerynck, K., Bachnick, S., Schwendimann, R., Schubert, M., De Geest, S., 
group, M. R. s. (2018). Work schedule flexibility is associated with emotional exhaustion among registered nurses in Swiss hospitals: A cross-sectional study. International Journal of Nursing Studies, 82, 99-105.

Engelbrecht, M., Rau, A., Kigozi, G., van Rensburg, A. J., Wouters, E., Sommerland, N.,Uebel, K. (2019). Waiting to inhale: factors associated with healthcare workers' fears of occupationally-acquired tuberculosis (TB). BMC Infectious Diseases, 19(1), 1-7.

Gefen, D., Straub, D., \& Boudreau, M.-C. (2000). Structural equation modeling and regression: Guidelines for research practice. Communications of the association for information systems, 4(1), 7.

Gössling, S., Scott, D., \& Hall, C. M. (2020). Pandemics, tourism and global change: a rapid assessment of COVID-19. Journal of Sustainable Tourism. https://doi.org/10.1080/09669582.2020.1758708

Greenhaus, J. H., \& Beutell, N. J. (1985). Sources of conflict between work and family roles. Academy of Management Review, 10(1), 76-88.

Hair, J. F., Risher, J. J., Sarstedt, M., \& Ringle, C. M. (2019). When to use and how to report the results of PLS-SEM. European Business Review, 31(1), 2-24.

Hammer, L. B., Kossek, E. E., Anger, W. K., Bodner, T., \& Zimmerman, K. L. (2011). Clarifying work-family intervention processes: The roles of work-family conflict and family-supportive supervisor behaviors. Journal of Applied Psychology, 96(1), 134.

Hartley, D. J., Davila, M. A., Marquart, J. W., \& Mullings, J. L. (2013). Fear is a disease: The impact of fear and exposure to infectious disease on correctional officer job stress and satisfaction. American Journal of Criminal Justice, 38(2), 323-340.

Henseler, J., Ringle, C. M., \& Sarstedt, M. (2015). A new criterion for assessing discriminant validity in variance-based structural equation modeling. Journal of the Academy of Marketing Science, 43(1), 115-135.

Hoobler, J. M., \& Brass, D. J. (2006). Abusive supervision and family undermining as displaced aggression. Journal of Applied Psychology, 91(5), 1125.

Huang, J., Han, M., Luo, T., Ren, A., \& Zhou, X. (2020). Mental health survey of 230 medical staff in a tertiary infectious disease hospital for COVID-19. Zhonghua lao dong wei sheng zhi ye bing za zhi= Zhonghua laodong weisheng zhiyebing zazhi= Chinese journal of industrial hygiene and occupational diseases, 38, E001-E001.

Huang, Y., \& Zhao, N. (2020). Generalized anxiety disorder, depressive symptoms and sleep quality during COVID-19 outbreak in China: a web-based cross-sectional survey. Psychiatry Research. https://doi.org/10.1016/j.psychres.2020.112954

Judge, T. A., \& Ilies, R. (2004). Affect and job satisfaction: a study of their relationship at work and at home. Journal of Applied Psychology, 89(4), 661.

Khalid, I., Khalid, T. J., Qabajah, M. R., Barnard, A. G., \& Qushmaq, I. A. (2016). Healthcare 
workers emotions, perceived stressors and coping strategies during a MERS-CoV outbreak. Clinical Medicine \& Research, 14(1), 7-14.

Li, W., Yang, Y., Liu, Z.-H., Zhao, Y.-J., Zhang, Q., Zhang, L.,Xiang, Y.-T. (2020). Progression of mental health services during the COVID-19 outbreak in China. International journal of biological sciences, 16(10), 17-32.

Liang, H., \& Acharya, G. (2020). Novel corona virus disease (COVID-19) in pregnancy: What clinical recommendations to follow? Acta Obstetricia et Gynecologica Scandinavica, 99(4), 439-442.

Liu, J., Kwan, H. K., Lee, C., \& Hui, C. (2013). Work-to-family spillover effects of workplace ostracism: The role of work-home segmentation preferences. Human Resource Management, 52(1), 75-93.

Meier, L. L., \& Cho, E. (2019). Work stressors and partner social undermining: Comparing negative affect and psychological detachment as mechanisms. Journal of Occupational Health Psychology, 24(3), 359.

Mujtaba, B. G. (2014). Managerial Skills and Practices for Global Leadership. ILEAD Academy: Florida.

Mujtaba, B.G., Senathip, T., and Sungkhawan, J. (2021). Task and Relationship Orientation of Professionals in Afghanistan and Thailand. Business Ethics and Leadership, 5(2), 6-20. https://doi.org/10.21272/bel.5(2).6-20.2021

Mujtaba, B. G., Cavico, F. J., and Senathip, T. (2020). Strategies for Personal, Organizational and Professional Leadership Success. Scientific Journal of Research \& Reviews, 2(3), 1-10.

Mujtaba, B. G. and Cavico, F. J. (2014). Wellness Programs and Means of Getting Employees to Stay Healthy: A Response to Kristin Van Busum and Soeren Mattke. International Journal of Health Policy and Management, 2(1), 47-48.

Podsakoff, P. M., MacKenzie, S. B., \& Podsakoff, N. P. (2012). Sources of method bias in social science research and recommendations on how to control it. Annual Review of Psychology, 63, 539-569.

Preacher, K. J., \& Hayes, A. F. (2008). Asymptotic and resampling strategies for assessing and comparing indirect effects in multiple mediator models. Behavior Research Methods, 40(3), 879-891.

Ren, S.-Y., Gao, R.-D., \& Chen, Y.-L. (2020). Fear can be more harmful than the severe acute respiratory syndrome coronavirus 2 in controlling the corona virus disease 2019 epidemic. World Journal of Clinical Cases, 8(4), 652.

Rodríguez-Muñoz, A., Antino, M., León-Pérez, J. M., \& Ruiz-Zorrilla, P. (2020). Workplace Bullying, Emotional Exhaustion, and Partner Social Undermining: A Weekly Diary Study. Journal of Interpersonal Violence. https://doi.org/10.1177/0886260520933031

Roy, D., Tripathy, S., Kar, S. K., Sharma, N., Verma, S. K., \& Kaushal, V. (2020). Study of 
knowledge, attitude, anxiety \& perceived mental healthcare need in Indian population during COVID-19 Asian Journal of Psychiatry. https://doi.org/10.1016/j.ajp.2020.102083

Salisbury, H. (2020). Helen Salisbury: Fear in the time of Covid. BMJ, 368. BMJ Publishing Group Ltd. https://www.bmj.com/content/368/bmj.m1286

Sarwar, A., Bashir, S., \& Karim Khan, A. (2019). Spillover of workplace bullying into family incivility: testing a mediated moderation model in a time-lagged study. Journal of Interpersonal Violence. https://doi.org/10.1177/0886260519847778

Sarwar, A., Irshad, M., Zhong, J. Y., Sarwar, S., \& Pasha, R. (2020). Effects of social undermining in families on deviant workplace behaviours in Pakistani nurses. Journal of Nursing Management. https://doi.org/10.1111/jonm.13027

Sarwar, A., \& Muhammad, L. (2020). Impact of employee perceptions of mistreatment on organizational performance in the hotel industry. International Journal of Contemporary Hospitality Management, 32(1), 230-248.

Sarwar, A., Naseer, S., \& Zhong, J. Y. (2020). Effects of bullying on job insecurity and deviant behaviors in nurses: Roles of resilience and support. Journal of Nursing Management, 28(2), 267-276.

Secon, H., Woodward, A., \& Mosher, D. (2020). A comprehensive timeline of the new coronavirus pandemic, from China's first COVID-19 case to the present. Business Insider. https://www.pulse.ng/bi/tech/a-comprehensive-timeline-of-the-new-coronavirus-pandemic-fr om-chinas-first-covid-19/4w28xmf

Shahid, A. (2020). Two coronavirus cases confirmed in Pakistan. Pakistan Today. https://www.pakistantoday.com.pk/2020/02/26/sindh-health-two-coronavirus-cases-confirme d-in-pakistan-confirms-first-coronavirus-case-in-karachi/

Shaikh, B., \& Ali, N. (2020). COVID-19 and fiscal space for health system in Pakistan: It is time for a policy decision. International Journal of Health Planning Management, 35, 813-817. https://doi.org/10.1002/hpm.2986

Shmueli, G., Sarstedt, M., Hair, J. F., Cheah, J.-H., Ting, H., Vaithilingam, S., \& Ringle, C. M. (2019). Predictive model assessment in PLS-SEM: guidelines for using PLSpredict. European Journal of Marketing, 53(11), 2322-2347.

Sohrabi, C., Alsafi, Z., O’Neill, N., Khan, M., Kerwan, A., Al-Jabir, A., \& Agha, R. (2020). World Health Organization declares global emergency: A review of the 2019 novel coronavirus (COVID-19). International Journal of Surgery, 76, 71-76.

Sonnentag, S., \& Binnewies, C. (2013). Daily affect spillover from work to home: Detachment from work and sleep as moderators. Journal of Vocational Behavior, 83(2), 198-208.

Staines, G. L. (1980). Spillover versus compensation: A review of the literature on the 
relationship between work and nonwork. Human relations, 33(2), 111-129.

Sun, W., Wu, M., Qu, P., Lu, C., \& Wang, L. (2014). Psychological well-being of people living with HIV/AIDS under the new epidemic characteristics in China and the risk factors: a population-based study. International Journal of Infectious Diseases, 28, 147-152.

Trépanier, S.-G., Fernet, C., \& Austin, S. (2013). Workplace bullying and psychological health at work: The mediating role of satisfaction of needs for autonomy, competence and relatedness. Work \& Stress, 27(2), 123-140.

Wang, J., Zhou, M., \& Liu, F. (2020). Reasons for healthcare workers becoming infected with novel coronavirus disease 2019 (Covid-19) in China. Journal of Hospital Infection, 20. https://doi.org/10.1016/j.jhin.2020.03.002

Wang, L.-s., Wang, Y.-r., Ye, D.-w., \& Liu, Q.-q. (2020). A review of the 2019 Novel Coronavirus (Covid-19) based on current evidence. International journal of antimicrobial agents. https://doi.org/10.1016/j.ijantimicag.2020.105948

Williams, K. J., \& Alliger, G. M. (1994). Role stressors, mood spillover, and perceptions of work-family conflict in employed parents. Academy of Management Journal, 37(4), 837-868.

Witte, G., Sheridan, M. B., Slater, J. and Sly, L. (2020). Global surge in coronavirus cases is being fed by the developing world — and the U.S. The Washington Post, July 14, 2020. https://apple.news/A9HWKH2vXTwSOIeiL3qpgcw

Wu, P., Fang, Y., Guan, Z., Fan, B., Kong, J., Yao, Z., Lu, J. (2009). The psychological impact of the SARS epidemic on hospital employees in China: exposure, risk perception, and altruistic acceptance of risk. The Canadian Journal of Psychiatry, 54(5), 302-311.

Yang, Y., Peng, F., Wang, R., Guan, K., Jiang, T., Xu, G., Chang, C. (2020). The deadly coronaviruses: The 2003 SARS pandemic and the 2020 novel coronavirus epidemic in China. Journal of autoimmunity. https://doi.org/10.1016/j.jaut.2020.102434

Zhang, X. and Yang, S. (2020). "A community system": A critical foundation for the epidemic prevention and control of SARS-CoV-2. International Journal of Health Planning and Management, pp. 1-4. https://doi.org/10.1002/hpm.3005

\section{Biography}

Somia Sarwar is a Gynecologist and running a private hospital in Toba Tek Singh, Pakistan. Her research interests include obesity, depression in healthcare workers, stressors experienced by healthcare workers and workplace behaviors of doctors.

Aisha Sarwar is a doctoral candidate at the Capital University of Science and Technology, Islamabad, Pakistan. She has published in International Journal of Contemporary and Hospitality Management (Emarald Publisher, Impact factor 5.6), Journal of Interpersonal Violence (Sage publisher, Impact factor 3.5), and the Journal of Nursing Management (Wiley online, Impact factor 2.3). Her research interests include personality, organizational stressors, 


\section{Macrothink \\ International Journal of Human Resource Studies \\ ISSN 2162-3058 \\ 2021, Vol. 11, No. 3}

employee emotions, and workplace behaviors.

Bahaudin G. Mujtaba is Professor of International Management and Human Resources at Nova Southeastern University in Ft. Lauderdale, Florida. Bahaudin is the author and co-author of several professional and academic books and research dealing with diversity, coaching, leadership, business ethics, and cross-cultural management, as well as numerous academic journal articles. During the past twenty-five years he has had the pleasure of working with human resource professionals in the United States, Brazil, Bahamas, Afghanistan, Pakistan, St. Lucia, Grenada, Malaysia, Japan, Vietnam, China, India, Thailand, and Jamaica. This diverse exposure has provided him cross-cultural insights in ethics, culture, and management from the perspectives of different firms, people groups, and countries.

Zia Ur Rehman is MS scholar at National University of Science and Technology, Islamabad, Pakistan. His research interests include manufacturing, CFD simulations, and other operation-related functions.

\section{Copyright Disclaimer}

Copyright for this article is retained by the author(s), with first publication rights granted to the journal.

This is an open-access article distributed under the terms and conditions of the Creative Commons Attribution license (http://creativecommons.org/licenses/by/4.0/). 